\title{
51. BREAKUP AND SEAFLOOR SPREADING BETWEEN THE KERGUELEN PLATEAU-LABUAN BASIN AND THE BROKEN RIDGE-DIAMANTINA ZONE ${ }^{1}$
}

\author{
Marc Munschy, ${ }^{2}$ Jérôme Dyment, ${ }^{2}$ Marie Odile Boulanger, ${ }^{2}$ Daniel Boulanger, ${ }^{2}$ Jean Daniel Tissot, ${ }^{2}$ \\ Roland Schlich, ${ }^{2}$ Yair Rotstein,,${ }^{2,3}$ and Millard F. Coffin ${ }^{4}$
}

\begin{abstract}
Using all available geophysical data and an interactive graphic software, we determined the structural scheme of the Australian-Antarctic and South Australian basins between the Kerguelen Plateau and Broken Ridge. Four JOIDES Resolution transit lines between Australia and the Kerguelen Plateau were used to study the detailed pattern of seafloor spreading at the Southeast Indian Ridge and the breakup history between the Kerguelen Plateau and Broken Ridge.

The development of rifting between the Kerguelen Plateau-Labuan Basin and the Broken Ridge-Diamantina Zone, and the evolution of the Southeast Indian Ridge can be summarized as follows:

1. From 96 to $46 \mathrm{Ma}$, slow spreading occurred between Antarctica and Australia; the Kerguelen Plateau, Labuan Basin, and Diamantina Zone stretched at 88-87 Ma and 69-66 Ma.

2. From 46 to $43 \mathrm{Ma}$, the breakup between the Southern Kerguelen Plateau and the Diamantina Zone propagated westward at a velocity of about $300 \mathrm{~km} / \mathrm{m}$.y. The breakup between the Northern Kerguelen Plateau and Broken Ridge occurred between 43.8 and $42.9 \mathrm{Ma}$.

3. After $43 \mathrm{Ma}$, volcanic activity developed on the Northern Kerguelen Plateau and at the southern end of the Ninetyeast Ridge. Lava flows obscured the boundaries of the Northern Kerguelen Plateau north of $48^{\circ} \mathrm{S}$ and of the Ninetyeast Ridge south of $32^{\circ} \mathrm{S}$, covering part of the newly created oceanic crust. Since $43 \mathrm{Ma}$, the Southeast Indian Ridge has manifested a typical intermediate spreading rate $(25-45 \mathrm{~km} / \mathrm{m} . \mathrm{y}$.$) .$
\end{abstract}

\section{INTRODUCTION}

Located in the southern Indian Ocean, the Kerguelen Plateau and Broken Ridge are a conjugate pair of ocean plateaus. They are separated by the Australian-Antarctic Basin and the South Australian Basin formed at the Southeast Indian Ridge (Fig. 1). Since 1967, many authors have interpreted the magnetic anomaly pattern associated with this spreading center between Saint Paul and Amsterdam islands and about $105^{\circ} \mathrm{E}$ (Schlich and Patriat, 1967, 1971; Le Pichon and Heirtzler, 1968; McKenzie and Sclater, 1971; Schlich, 1975, 1982; Houtz et al., 1977; Li, 1988; Royer and Schlich, 1988; Royer and Sandwell, 1989). The most detailed tectonic chart of this area (Royer and Sandwell, 1989), however, is based on $<100$ magnetic anomaly identifications; only five reversal boundaries were selected for plate reconstructions.

Until recently, the breakup history between the Kerguelen Plateau and Broken Ridge was a matter of controversy. The original reconstructions of Australia and Antarctica (McKenzie and Sclater, 1971; Weissel and Hayes, 1972) proposed separation of the two continents at Anomaly 22 (52 Ma on the 1985 Berggren et al. geomagnetic reversal time scale). Houtz et al. (1977) showed that, before $45 \mathrm{Ma}$, the Northern Ker-

\footnotetext{
${ }^{1}$ Wise, S. W., Jr., Schlich, R., et al., 1992. Proc. ODP, Sci. Results, 120: College Station, TX (Ocean Drilling Program).

2 Institut de Physique du Globe, Université Louis Pasteur, Laboratoire de Géophysique Marine (CNRS URA 323), 5 rue René Descartes, 67084 Strasbourg Cedex, France.

${ }^{3}$ Also at Institute for Petroleum Research and Geophysics, P. O.Box 2286. Holon 58120, Israel.

${ }^{4}$ Bureau of Mineral Resources, Geology and Geophysics, G.P.O. Box 378, Canberra ACT 2601, Australia (present address: Institute for Geophysics, University of Texas at Austin, 8701 Mopac Boulevard, Austin, TX 78759-8345, U.S.A.).
}

guelen Plateau and Broken Ridge would overlap if Broken Ridge were rotated using the poles of opening determined by Weissel and Hayes (1972) between Australia and Antarctica. Such a mismatch problem was resolved by assuming that the Northern Kerguelen Plateau is younger than $45 \mathrm{Ma}$, and numerous authors have, more or less, followed this hypothesis (Luyendyk and Rennick, 1977; Norton and Molnar, 1977; Norton and Sclater, 1979; Goslin, 1981; Schlich, 1982). Piston core and dredge samples, however, have shown that the part of the Northern Kerguelen Plateau located south of Kerguelen Island is at least $100 \mathrm{Ma}$ (Fröhlich et al., 1983; Wicquart, 1983).

Furthermore, lithostratigraphic (Wicquart and Fröhlich, 1986) and seismic stratigraphic (Munschy and Schlich, 1987) studies on the Kerguelen Plateau, as well as Ocean Drilling Program (ODP) results on Broken Ridge (Peirce, Weissel, et al., 1989; Weissel, Peirce, et al., 1991) suggest that the breakup between the Northern Kerguelen Plateau and Broken Ridge occurred at 45-42 Ma. East of the Southern Kerguelen Plateau, Anomalies 17 and 18 (41 and $42 \mathrm{Ma}$ ) have been clearly identified (Le Pichon and Heirtzler, 1968; Houtz et al., 1977). However, these anomalies lie several hundred kilometers east of the Southern Kergueler Plateau eastern margin. Coffin et al. (1986) and Rotstein et al. (1991) have studied the area located between the eastern margin of the Southern Kerguelen Plateau and the oceanic crust created since Anomaly 18 (42 Ma) at the axis of the Southeast Indian Ridge. This area corresponds to the Labuan Basin, a deep Cretaceous basin, bounded to the north by the Williams Ridge, a northwestsoutheast elongated bathymetric feature.

Recently, Royer and Sandwell (1989) proposed a new tectonic chart for the area located east of the Kerguelen Plateau, based on available magnetic identifications and an interpretation of GEOSAT altimetric data. Their reconstruc- 


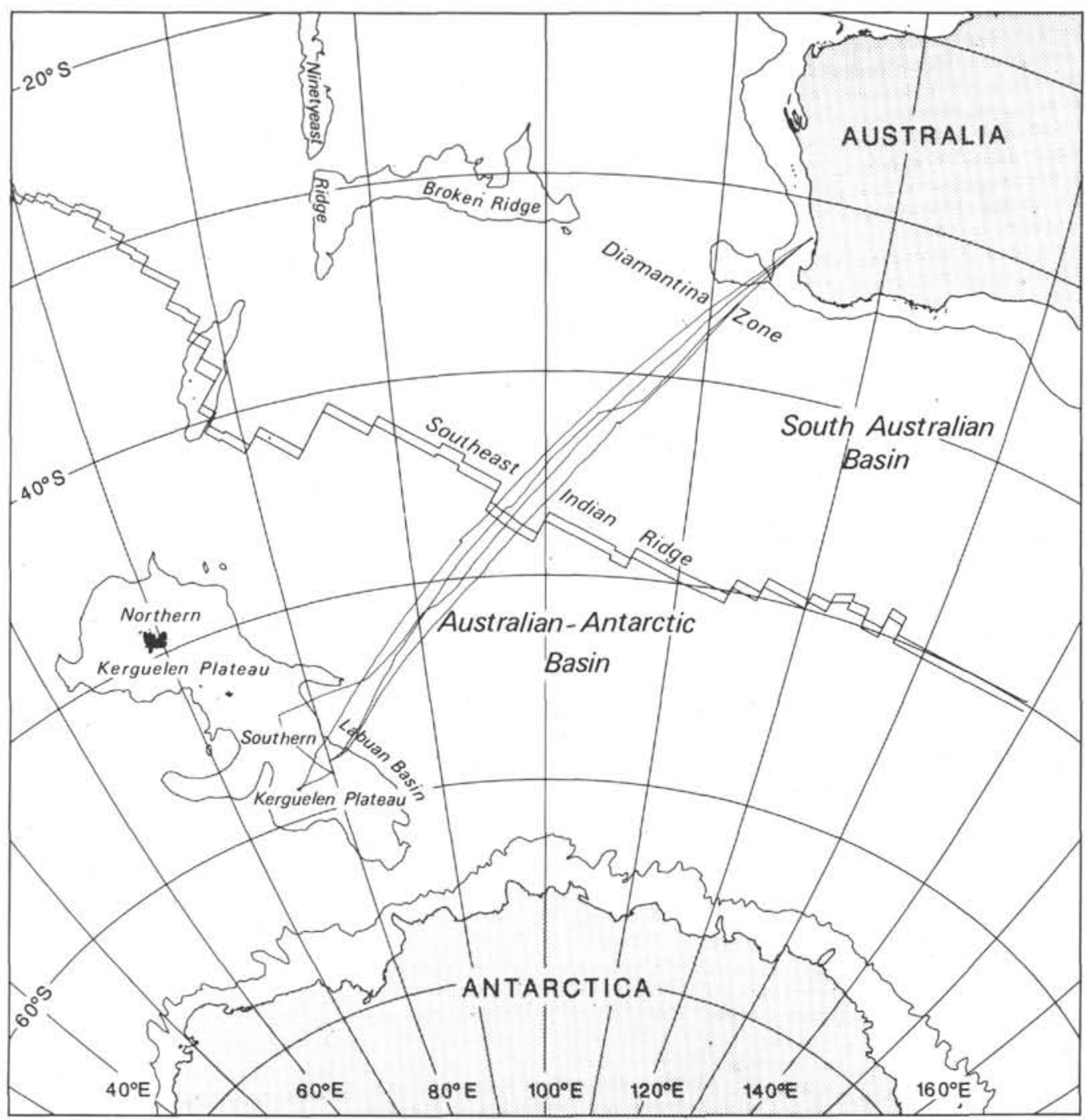

Figure 1. Location of the main bathymetric features in the Southeast Indian Ocean, outlined by the 3000-m isobath, and ship tracks of the JOIDES Resolution during Leg 120.

tions at Anomalies 13 and 18 resolve the mismatch problem between the Kerguelen Plateau and Broken Ridge. They propose that the northwesternmost part of the Kerguelen Plateau, which includes Kerguelen Island, is underlain by late Eocene/early Oligocene oceanic crust. However, this work was based on only a few anomaly identifications (three Anomaly 18 picks and eight Anomaly 13 picks), and the seismic profiles across the eastern margin of the Kerguelen Plateau were not used. Such profiles are crucial, especially the ones cutting the boundary that separates the Labuan Basin and the crust created at the axis of the Southeast Indian Ridge.

This paper considers all available magnetic profiles located east of the Kerguelen Plateau and uses, in particular, the four transit lines acquired during Leg 120 (Fig. 1). A detailed interpretation with accurate spreading rates and directions is proposed for the Southeast Indian Ridge since the middle Eocene. Magnetic picks on both flanks of the Southeast Indian Ridge are used to define a detailed tectonic chart. Combining the magnetic anomaly identifications with the interpretation of seismic profiles crossing the eastern boundary of the Kerguelen Plateau provides additional constraints for the breakup history of the Kerguelen Plateau.

\section{STRUCTURE AND EVOLUTION OF THE SOUTHEAST INDIAN RIDGE BETWEEN THE KERGUELEN PLATEAU AND BROKEN RIDGE}

Using all available marine geophysical data and an interactive graphic software, we identified 2500 magnetic picks on the southwestern flank of the Southeast Indian Ridge and 2100 magnetic picks on its northeastern flank and have derived a detailed tectonic chart. For this study, all recognized reversals of the geomagnetic field on all magnetic anomaly profiles were picked (146 reversals of the geomagnetic field since $44.5 \mathrm{Ma}$ ). To simplify discussion and presentation of the figures, we selected 53 isochrons or magnetic lineations on each flank of the Southeast Indian Ridge (Table 1). We used the nomenclature of Berggren et al. (1985) to identify the magnetic lineations and the corresponding magnetic picks; the letters " $y$ " and "o" refer to the younger and older reversals, respectively, in a normal polarity interval.

\section{Detailed Analysis of Compartment L}

Underway geophysical data, including magnetics, were recorded across the Southeast Indian Ridge during four 
Table 1. Geomagnetic reversal time scale between Anomalies 1 and 19.

\begin{tabular}{|c|c|c|c|c|c|}
\hline Anomaly & $\begin{array}{c}\text { Normal } \\
\text { polarity } \\
\text { interval } \\
(\mathrm{Ma})\end{array}$ & Anomaly & $\begin{array}{c}\text { Normal } \\
\text { polarity } \\
\text { interval } \\
(\mathrm{Ma})\end{array}$ & Anomaly & $\begin{array}{c}\text { Normal } \\
\text { polarity } \\
\text { interval } \\
(\mathrm{Ma})\end{array}$ \\
\hline \multirow[t]{2}{*}{1} & $0-0.73$ & & $12.58-12.62$ & 8 & $26.86-26.93$ \\
\hline & $0.91-0.98$ & 5AA & $12.83-13.01$ & 8 & $27.01-27.74$ \\
\hline 2 & $1.66-1.88$ & $5 \mathrm{AB}$ & $13.20-13.46$ & 9 & $28.15-28.74$ \\
\hline $2 \mathrm{~A}$ & $2.47-2.92$ & $5 \mathrm{AC}$ & $13.69-14.08$ & 9 & $28.80-29.21$ \\
\hline $2 \mathrm{~A}$ & $2.99-3.08$ & $5 \mathrm{AD}$ & $14.20-14.66$ & 10 & $29.73-30.03$ \\
\hline $2 \mathrm{~A}$ & $3.18-3.40$ & $5 B$ & $14.87-14.96$ & 10 & $30.09-30.33$ \\
\hline 3 & $3.88-3.97$ & $5 B$ & $15.13-15.27$ & II & $31.23-31.58$ \\
\hline 3 & $4.10-4.24$ & SC & $16.22-16.52$ & 11 & $31.64-32.06$ \\
\hline 3 & $4.40-4.47$ & $5 C$ & $16.56-16.73$ & 12 & $32.46-32.90$ \\
\hline 3 & $4.57-4.77$ & $5 \mathrm{C}$ & $16.80-16.98$ & 13 & $35.29-35.47$ \\
\hline $3 \mathrm{~A}$ & $5.35-5.53$ & 5D & $17.57-17.90$ & 13 & $35.57-35.87$ \\
\hline \multirow[t]{2}{*}{$3 \mathrm{~A}$} & $5.68-5.89$ & 5D & $18.12-18.14$ & 15 & $37.24-37.46$ \\
\hline & $6.37-6.50$ & $S E$ & $18.56-19.09$ & 15 & $37.48-37.68$ \\
\hline 4 & $6.70-6.78$ & 6 & $19.35-20.45$ & 16 & $38.10-38.34$ \\
\hline 4 & $6.85-7.28$ & $6 \mathrm{~A}$ & $20.88-21.16$ & 16 & $38.50-38.79$ \\
\hline 4 & $7.35-7.41$ & $6 A$ & $21.38-21.71$ & 16 & $38.83-39.24$ \\
\hline $4 \mathrm{~A}$ & $7.90-8.21$ & $6 \mathrm{AA}$ & $21.90-22.06$ & 17 & $39.53-40.43$ \\
\hline \multirow[t]{2}{*}{$4 A$} & $8.41-8.50$ & $6 A A$ & $22.25-22.35$ & 17 & $40.50-40.70$ \\
\hline & $8.71-8.80$ & $6 \mathrm{~B}$ & $22.57-22.97$ & 17 & $40.77-41.11$ \\
\hline \multirow[t]{3}{*}{5} & $8.92-10.42$ & $6 C$ & $23.27-23.44$ & 18 & $41.29-41.73$ \\
\hline & $10.54-10.59$ & $6 \mathrm{C}$ & $23.55-23.79$ & 18 & $41.80-42.23$ \\
\hline & $11.03-11.09$ & 6C & $24.04-24.21$ & 18 & $42.30-42.73$ \\
\hline $5 \mathrm{~A}$ & $11.55-11.73$ & 7 & $25.50-25.60$ & 19 & $43.60-44.06$ \\
\hline \multirow[t]{2}{*}{$5 A$} & $11.86-12.12$ & 7 & $25.67-25.97$ & & \\
\hline & $12.46-12.49$ & $7 \mathrm{~A}$ & $26.38-26.56$ & & \\
\hline
\end{tabular}

Notes: Time scale after Berggren et al. (1985). Reversals of the magnetic field selected in this paper are shown in boldface type.

JOIDES Resolution transits between Freemantle and the Kerguelen Plateau (Schlich, Wise, et al., 1989). These profiles, combined with older Eltanin data, provide good coverage of a segment of the Southeast Indian Ridge, delimited by two fracture zones, which we call Compartment $\mathrm{L}$ for consistency with later systematic notations. At this scale, the seafloor-spreading patterns appear neither perfectly linear nor perfectly symmetrical (Fig. 2). Magnetic Lineations $3 \mathrm{~A}$ to 1 are increasingly oblique (up to $10^{\circ}$ ) to the trend of the ridge axis. Asymmetric spreading was also observed in Compartment L (Fig. 3).

Spreading rates and directions related to each of the 14 magnetic lineations identified between Anomalies 5o and 1 are shown in Figure 3. An average $30-\mathrm{km} / \mathrm{m}$.y. half-spreading rate for the 5o-3Ao period, followed by an average $43-\mathrm{km} / \mathrm{m}$. y. rate for the period $3 \mathrm{Ao}-2 \mathrm{Ay}$, a lower $30-\mathrm{km} / \mathrm{m} . \mathrm{y}$. rate at Anomaly 2, and a higher $40-\mathrm{km} / \mathrm{m}$.y. rate from Anomaly 1 to the present were observed. The asymmetry varies with time, with periods producing more crust on the northern $(2-2 A$, $3 \mathrm{Ao}-4 \mathrm{Ao}$, and 5$)$ and southern flanks (2Ao-3o and $4 \mathrm{~A})$. The highest asymmetry ( $30 \mathrm{vs.} 44 \mathrm{~km} / \mathrm{m}$.y. at Anomaly 2) and the cumulative asymmetry between Anomalies 1 and 5 added more crust on the northern flank.

Two changes of directions were observed, one between Anomaly 4 and $3 \mathrm{~A}$, and the other during the Jaramillo Magnetic Event. They do not exceed $6^{\circ}$ and are associated with variations in spreading rates and asymmetry. The highest asymmetry values are related to these changes of direction.

\section{Regional Description of the Southeast Indian Ridge between the Kerguelen Plateau and Broken Ridge}

Magnetic lineations and fracture zones were identified along the Southeast Indian Ridge between $32^{\circ} \mathrm{S}-76^{\circ} \mathrm{E}$ and $49^{\circ} \mathrm{S}-106^{\circ} \mathrm{E}$, and the anomalies were identified as ranging in age from $45 \mathrm{Ma}$ to the present (Fig. 4). This interval corresponds roughly to the period of seafloor spreading between the northeastern flank of the Kerguelen Plateau and the southern flank of Broken Ridge. On a large scale, the presentday ridge axis displays 14 compartments, noted $\mathrm{A}$ to $\mathrm{N}$ from north to south, separated by 13 fracture zones. Second-order ridge segmentation was observed within Compartments B and $\mathrm{F}$, although it probably exists in other compartments but cannot be resolved with the present data set. Three different zones can be recognized within the area studied.

The northwestern zone, which includes Compartments A and $\mathrm{B}$, is part of a larger zone ending at the Rodriguez Triple Junction, already described by Royer and Schlich (1988). Compartments A and B are fairly wide (about $215 \mathrm{~km}$ ), and the fracture zone offsets in the northwestern zone average $85 \mathrm{~km}$. The Amsterdam-Saint Paul Zone, which includes Compartments C, D, and E, shows narrow compartments separated by large offset fracture zones. The typical width of the compartments is $115 \mathrm{~km}$, and the average fracture zone offset is about $120 \mathrm{~km}$. All transform faults display sinistral relative motion, and the cumulative offset reaches $490 \mathrm{~km}$. During the last major plate reorganization of the Indian Ocean, which occurred at about $43 \mathrm{Ma}$, the Amsterdam-Saint Paul Zone represented a junction between two very different parts of the Southeast Indian Ridge: the old northwestern part has separated Antarctica and India since at least Anomaly 34 (84 Ma), whereas the newly created southeastern part definitely split Antarctica and Australia.

In Compartment D lie the Amsterdam and Saint Paul volcanic islands, which could be related to hotspot activity (e.g., Morgan, 1978; Luyendyk and Rennick, 1977). Several indications, such as shallow bathymetry, high magnetic anomaly amplitude, and geochemical contamination of typical mid-oceanic ridge tholeiitic basalts by oceanic-island basalts (Royer, 1985; Royer and Schlich, 1988) demonstrate that this zone is unique.

The southeastern zone includes Compartments $\mathrm{F}$ to $\mathrm{N}$ and displays wide compartments (about $265 \mathrm{~km}$ ). The average fracture zone offset varies between 20 and $290 \mathrm{~km}$ and averages $95 \mathrm{~km}$. Nevertheless, the smallest offsets correspond 


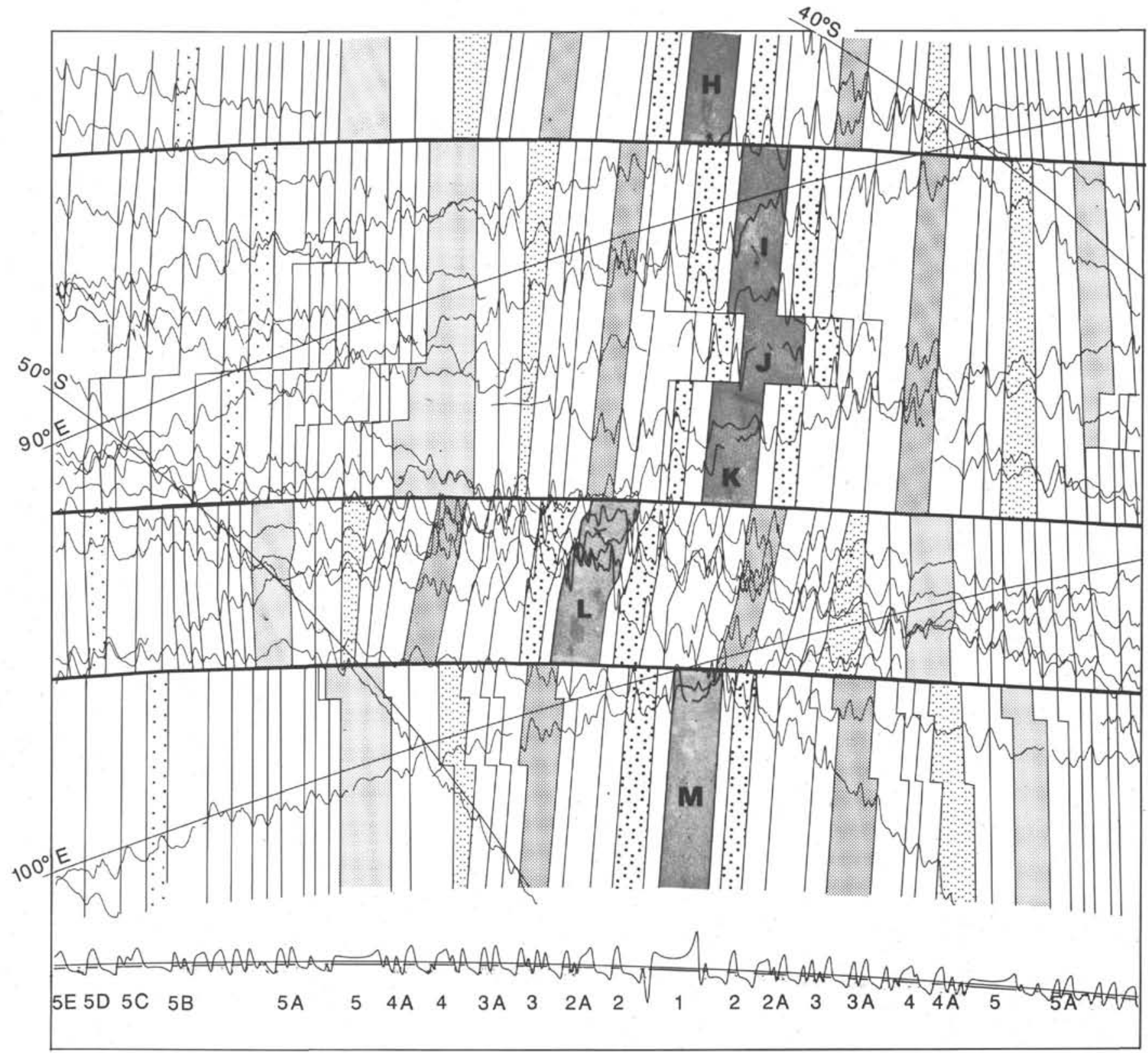

Figure 2. Magnetic anomalies and identified lineations associated with the Southeast Indian Ridge between Anomalies 1 and 5 in Compartments $\mathrm{H}$ to M. A perspective projection centered on $47^{\circ} \mathrm{S}$ and $96^{\circ} \mathrm{E}$ is used with an inclination of $56^{\circ}$ and a declination of $-62^{\circ}$. The corresponding synthetic magnetic profile is shown for reference.

to recently formed fracture zones such as E-F, I-J, J-K, and $\mathrm{M}-\mathrm{N}$. Excluding these fracture zones, the average offset is 130 $\mathrm{km}$. Also, the relative motion involved at the transform faults changes along the southeastern zone: it is dextral from $\mathrm{F}-\mathrm{G}$ to $\mathrm{I}-\mathrm{J}$, sinistral at $\mathrm{J}-\mathrm{K}$ and $\mathrm{K}-\mathrm{L}$, dextral at $\mathrm{L}-\mathrm{M}$, and sinistral at $\mathrm{M}-\mathrm{N}$. The spreading axis roughly follows the shape of the Kerguelen Plateau and Broken Ridge edges.

Despite the observation of several short-lived, small offset fracture zones and second-order ridge segmentation in some compartments, the overall aspect of the 53 magnetic lineations, which represent past ridge axis configurations, is similar to the present-day configuration. Most of the transform faults, and especially those involving great offset, have existed since the breakup between the Kerguelen Plateau and Broken Ridge. Several of the shortest lived, small offset structures are probably artifacts related to navigation errors as some of the cruises predate satellite navigation. However, other transient offsets were observed on both flanks of the ridge and are well established therefore.

The ridge configurations between Anomalies 18 and 8 and between Anomalies 3 and 1 seem to display more of these transient offsets, either small offset fracture zones or secondorder ridge segmentation. This could be related to the fact that the data coverage is more dense over the present spreading axis. However, some slight offsets between adjacent initial rift units may evolve into small offset fracture zones and/or second-order ridge segmentation and progressively disappear while normal seafloor spreading is established. This simplification of the ridge axis configuration is quite well demonstrated, for instance, by the comparison of Lineations 5 and 

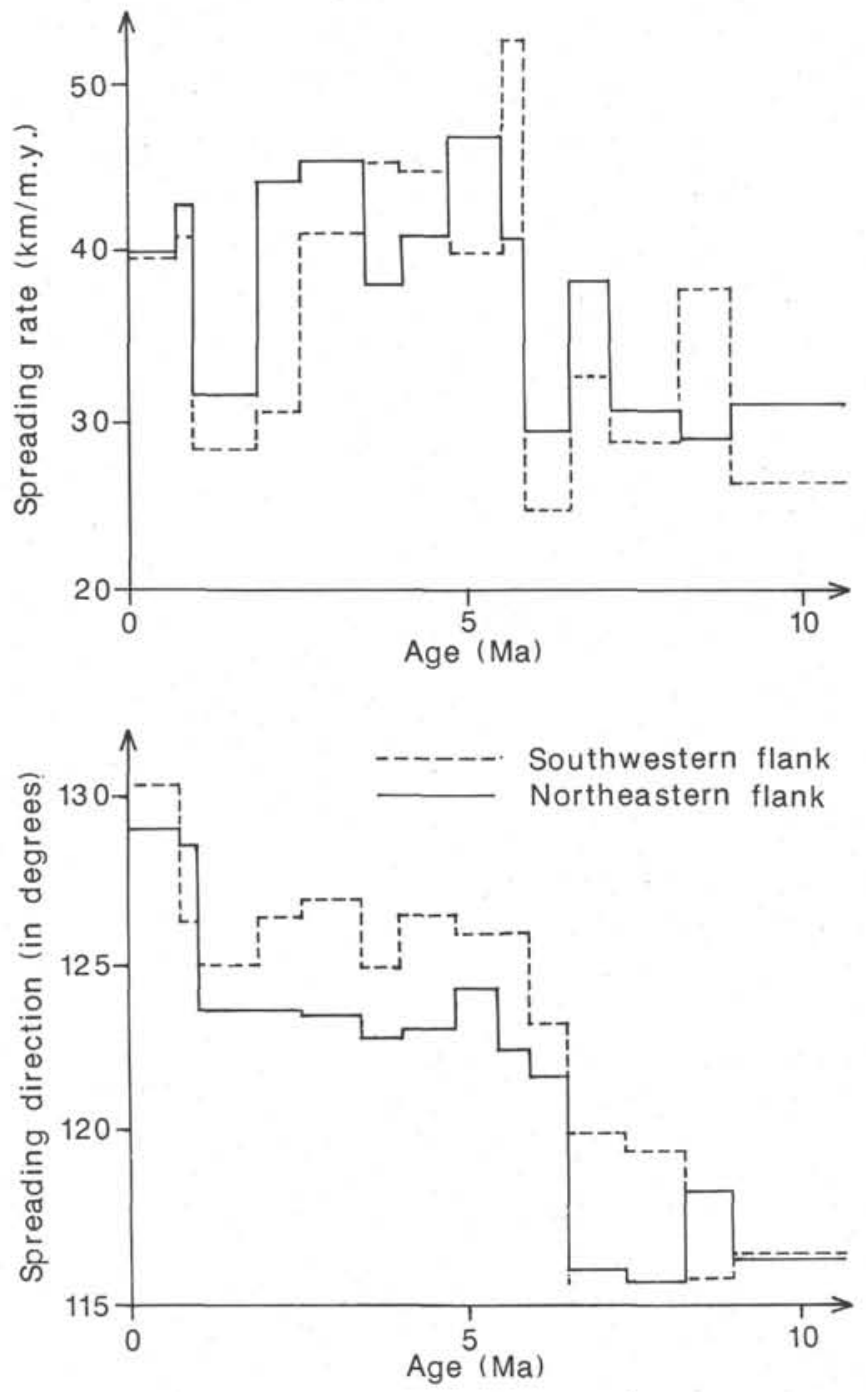

Figure 3. Variations of the half spreading rates and directions in Compartment L.

13. One fracture zone "captured" by another one can be observed in the vicinity of the Northern Kerguelen Plateau. Such a capture is associated with local ridge jumps, as observed in Compartment $\mathrm{G}$ at Anomaly 13, when a small part of the Antarctic Plate was transferred to the Indian Plate.

\section{BREAKUP BETWEEN THE KERGUELEN PLATEAU AND BROKEN RIDGE}

The boundary that separates the Kerguelen Plateau and the Australian-Antarctic Basin, and its conjugate, which lies between the South Australian Basin and the Broken RidgeDiamantina Zone, are about $2500 \mathrm{~km}$ long and can be divided into three morphologically different zones: (1) the northeastern boundary of the Labuan Basin and the southern boundary of the Diamantina Zone; (2) the northeastern boundary of the Northern Kerguelen Plateau south of $48^{\circ} \mathrm{S}$ and the southern boundary of Broken Ridge; and (3) the northeastern boundary of the Northern Kerguelen Plateau north of $48^{\circ} \mathrm{S}$ and the southern boundary of the Ninetyeast Ridge (Fig. 1).

The Northeastern Boundary of the Labuan Basin and the Southern Boundary of the Diamantina Zone

The Labuan Basin (Coffin et al., 1986; Ramsay et al., 1986; Rotstein et al., 1991) is a deep, extensive basement depres- sion, more than $350,000 \mathrm{~km}^{2}$ in area, adjacent to the eastern margin of the Southern Kerguelen Plateau. The age of the basement has been estimated at 130-100 Ma (Rotstein et al., 1991), and 96-43 Ma (Royer and Sandwell, 1989). The basement displays rather rough topography, which has been interpreted as the result of slow spreading (Royer and Sandwell, 1989) or as the result of an extensional tectonic event that occurred 75-68 m.y. ago (Rotstein et al., 1991). There is a $1-1.5 \mathrm{~km}$ difference between the basement elevation of the Labuan Basin and the Australian-Antarctic Basin, as well as a large difference in sedimentary thickness between them. A large gravity anomaly, as recorded by satellite altimeters (Coffin et al., 1986; Royer and Sandwell, 1989), is associated with the boundary.

The Diamantina Zone is the northern counterpart of the Labuan Basin. Before 1978, it was called the "Diamantina Fracture Zone" (Heezen and Tharp, 1965). Talwani et al. (1978) were the first to call it the "Diamantina Zone" to avoid confusion with well-defined oceanic fracture zones. The Diamantina Zone is an elongated area, about $200 \mathrm{~km}$ long, that extends from the eastern end of Broken Ridge to $120^{\circ}-125^{\circ} \mathrm{E}$ (Hayes and Conolly, 1972; Talwani et al., 1978). It displays very rugged topography, with two or three major troughs elongated in an east-trending direction. The rough topography of the eastern portion of the Diamantina Zone south of Australia, between $115^{\circ} \mathrm{E}$ and $120^{\circ}-125^{\circ} \mathrm{E}$, is attributed to very slow seafloor spreading $(4.5-10 \mathrm{~km} / \mathrm{m} . \mathrm{y}$.) at the Southeast Indian Ridge axis between Anomalies 34 and 19 (Cande and Mutter, 1982; Mutter et al., 1985). Such a mechanism of formation has also been proposed for the western Diamantina Zone (Markl, 1978; Royer and Sandwell, 1989). However, Mutter and Cande (1983) note some similarities between the "horst and graben" structure of the Kerguelen Plateau and the Diamantina Zone. Mammerickx and Sandwell (1986) proposed that the southern boundary of the Diamantina Zone corresponds to a scar left in the topography by the rifting that separated Australia and Antarctica.

The boundary between the Labuan Basin and the Australian-Antarctic Basin has been crossed by ten magnetic and bathymetric profiles, including four Joides Resolution Leg 120 lines, three multichannel seismic profiles (MD 47-08, MD 47-10, and RS 02-33), and one single channel seismic profile (EL 54-02). The complete sequence of Anomalies 18 to 13 is generally well observed on the magnetic profiles (Fig. 5). The mean half-spreading rate for this period of time is 27.7 $\mathrm{km} / \mathrm{m} . \mathrm{y}$., and the mean spreading direction is N35 . Since Anomaly 15, the Southeast Indian Ridge has been divided in this area into four main ridge compartments (denoted $\mathrm{K}$ to $\mathrm{N}$ ). Between Anomalies 18 and 15, no transform faults existed between Compartments $\mathrm{L}, \mathrm{M}$, and $\mathrm{N}$, and the lineations bend from $\mathrm{N} 106^{\circ}$ (spreading direction $\mathrm{N} 16^{\circ}$ ) to $\mathrm{N} 136^{\circ}$ (spreading direction $\mathrm{N} 46^{\circ}$ ). Extrapolating the half-spreading rate obtained between Anomalies 18 and 13 back to Anomaly 21, Anomaly 19 can be identified in Compartments $\mathrm{L}$ and $\mathrm{M}$. There is no magnetic profile in Compartment $\mathrm{N}$ to test this interpretation, and the four magnetic profiles in Compartment $\mathrm{K}$ show that Anomaly 19 is not present. Southwest of Anomaly 19 in Compartments L and M, and southwest of Anomaly 18 in Compartment $\mathrm{K}$, the magnetic profiles clearly show that no magnetic lineation associated with seafloor spreading exists in this area.

The boundary between the Labuan Basin and the Australian-Antarctic Basin is clearly shown on single channel seismic profile Eltanin 54-02 (Fig. 6A). The oceanic crust created at the Southeast Indian Ridge is at a depth of about $6 \mathrm{~s}$ two-way traveltime (twt) and is covered by $<0.2 \mathrm{~s}$ twt of sediments. The Labuan Basin basement is at a depth of about $7-8 \mathrm{~s}$ twt, and the sediment thickness varies from 0.2 to $1.7 \mathrm{~s}$ 


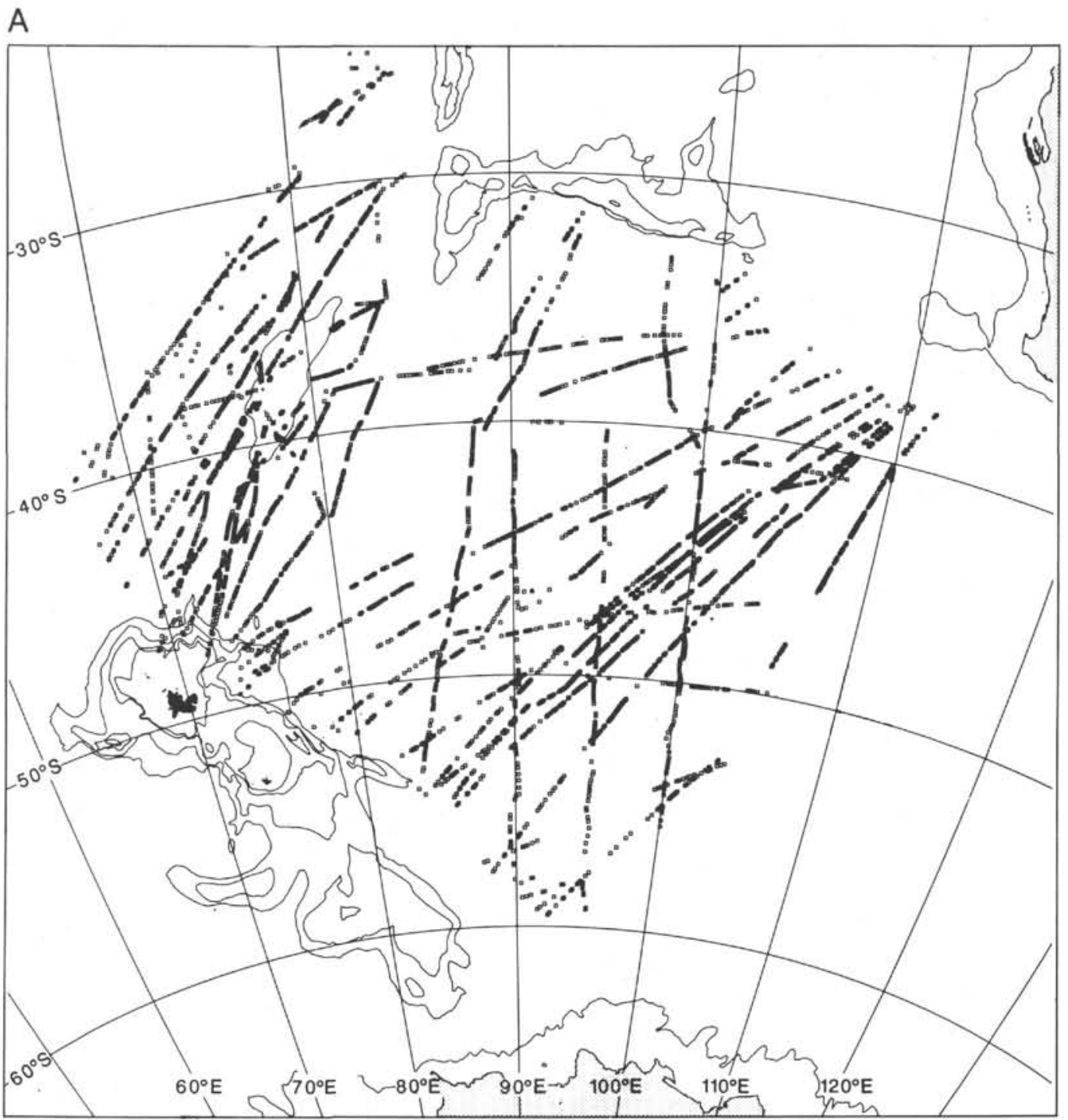

Figure 4. Magnetic picks (A) and identified magnetic lineations (B) between the Kerguelen Plateau and Broken Ridge. Isobaths $500,1000,2000$, and $3000 \mathrm{~m}$ on the Kerguelen Plateau, Broken Ridge, and Ninetyeast Ridge are derived from our data set.

twt. The boundary corresponds to a zone $>20 \mathrm{~km}$ wide. Extrapolating the spreading rate determined between Anomalies 13 and 18, the oceanic crust that abuts the Labuan Basin is $42.6 \pm 0.2 \mathrm{Ma}$. Farther southeast, the boundary was also observed on multichannel seismic profile Rig Seismic 02-33. Again, it corresponds to a zone $>20 \mathrm{~km}$ wide, and the basement elevation difference is about $1 \mathrm{~s} \mathrm{twt} \mathrm{(Fig.} \mathrm{6B).} \mathrm{Along}$ this profile, the greatest age for the oceanic crust created at the Southeast Indian Ridge is $43.8 \pm 0.2 \mathrm{Ma}$. Profiles Marion Dufresne 47-08 and 47-10 show a less pronounced boundary between the Labuan and Australian-Antarctic basins (Fig. 6C and 6D). To the northeast, the oceanic crust created at the Southeast Indian Ridge axis was observed clearly until Anomaly 18 (shot point 12800 on profile MD 47-08 and shot point 2000 on profile MD 47-10). To the southwest, the Labuan Basin basement was clearly observed on profile MD 47-10 until shot point 3600 and on profile MD 47-08 until shot point 10000 . In the vicinity of these two profiles, the boundary between the Labuan Basin and the Australian-Antarctic Basin is an 80- (profile MD 47-10) to $140-\mathrm{km}$ (profile MD 47-08) wide zone. However, if we assume that the interpretation of Anomaly 19 on profiles MD 47-10 and MD 47-08 is correct, the width of this boundary may be reduced to $35-90 \mathrm{~km}$, with a mean age of $44.5 \pm 1.3 \mathrm{Ma}$ and $45.9 \pm 3.2 \mathrm{Ma}$, respectively.

The boundary between the Diamantina Zone and the South Australian Basin is crossed by 14 magnetic and bathymetric profiles, including four Joides Resolution Leg 120 lines. The complete sequence of Magnetic Anomalies 18-13 is generally well observed on the magnetic profiles (Fig. 7). The mean half-spreading rate for this period (from 35.29 to $42.73 \mathrm{Ma}$ ) is $25.5 \mathrm{~km} / \mathrm{m}$.y., and the mean spreading direction is $\mathrm{N} 23^{\circ}$. A curvature in the magnetic lineations was observed for Anomalies 15-18 inside Compartments L, M, and N. Anomaly 19 was identified inside Compartments $\mathrm{M}$ and N. Before Anomaly 19 , the magnetic profiles are similar to those observed in the Labuan Basin, and no magnetic lineations associated with seafloor spreading have been identified.

Only two seismic profiles in the western Diamantina Zone have been published (Houtz and Markl, 1972; Markl, 1978). Despite the low quality of the sections, the western Diaman- 
B

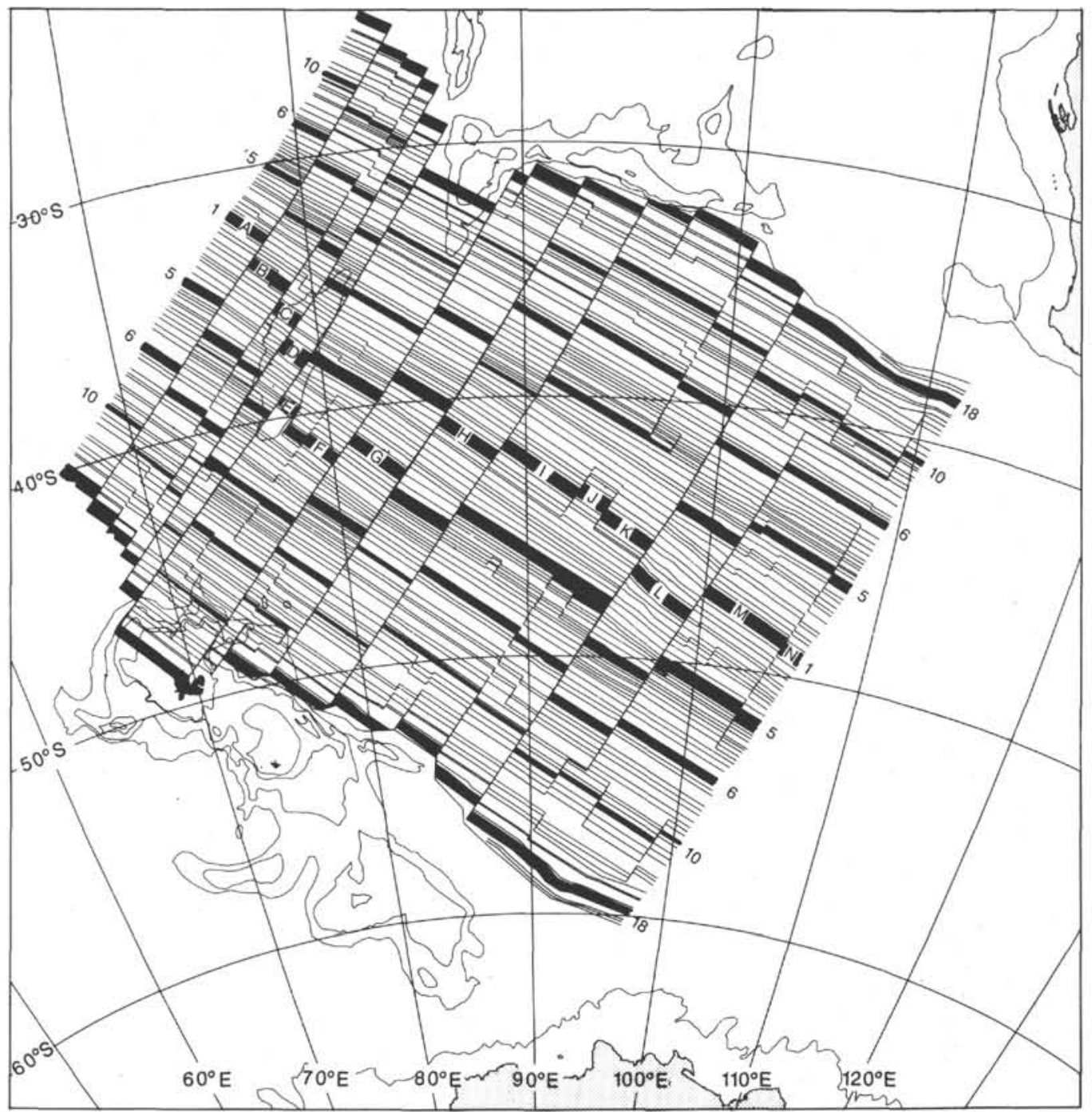

Figure 4 (continued).

tina Zone and the Labuan Basin show similar basement structures. The roughness of the basement reflector appears to be related to faults and tilted block morphology, as observed in the Labuan Basin (Rotstein et al., 1991). The basement reflector is generally smooth for individual blocks, and the roughness results from the vertical throw of the bounding faults. The faults and tilted block morphology are similar to that of the Labuan Basin; the vertical throw of the main faults reaches over $1000 \mathrm{~m}$ and the tilted blocks are $10-50 \mathrm{~km}$ wide. As in the Labuan Basin (Rotstein et al., 1991), their geographical distribution, on the two profiles available, does not show a "basin and range" type of distributed extension; instead, the tilted blocks are divided into distinct groups of southward- or northward-dipping block surfaces.

It is difficult to consider the Diamantina Zone as the result of slow seafloor spreading at the Southeast Indian Ridge axis. Although slow spreading ridges also display a faulted basement, their topography is not smooth between faults (see, e.g., Macdonald, 1982, for a review). Moreover, in the Labuan Basin, the faults were clearly initiated after basement formation: the deepest seismic reflectors, directly above basement, are also faulted. Such faulting, following sediment deposition, was not observed on the slow spreading ridge flanks.

The boundary between the crust generated at the Southeast Indian Ridge and the Diamantina Zone is well observed on the seismic section published by Markl (1978, fig. 3E) and corresponds to a topographic trough. A similar trough was also seen on the bathymetric profiles crossing the Diamantina Zone. We define the boundary between the South Australian Basin and the Diamantina Zone by the southern wall of this trough. The age of the boundary, extrapolated from the spreading rates between Anomalies 13 and 18, ranges between $46.0 \pm 0.4 \mathrm{Ma}$ to the east $\left(37.44^{\circ} \mathrm{S}\right.$ and $\left.111.84^{\circ} \mathrm{E}\right)$ and $43.0 \pm$ $0.4 \mathrm{Ma}$ to the west $\left(34.61^{\circ} \mathrm{S}\right.$ and $\left.102.12^{\circ} \mathrm{E}\right)$ along the western 'Diamantina Zone.

\section{The Northeastern Boundary of the Northern Kerguelen Plateau South of $48^{\circ} \mathrm{S}$ and the Southern Boundary of Broken Ridge}

The northeastern flank of the Northern Kerguelen Plateau and the southern flank of Broken Ridge are characterized by steep escarpments ranging from $500-1000$ to $3000-4000 \mathrm{~m}$. A deep trough, the Ob Trench, was observed at the foot of the 


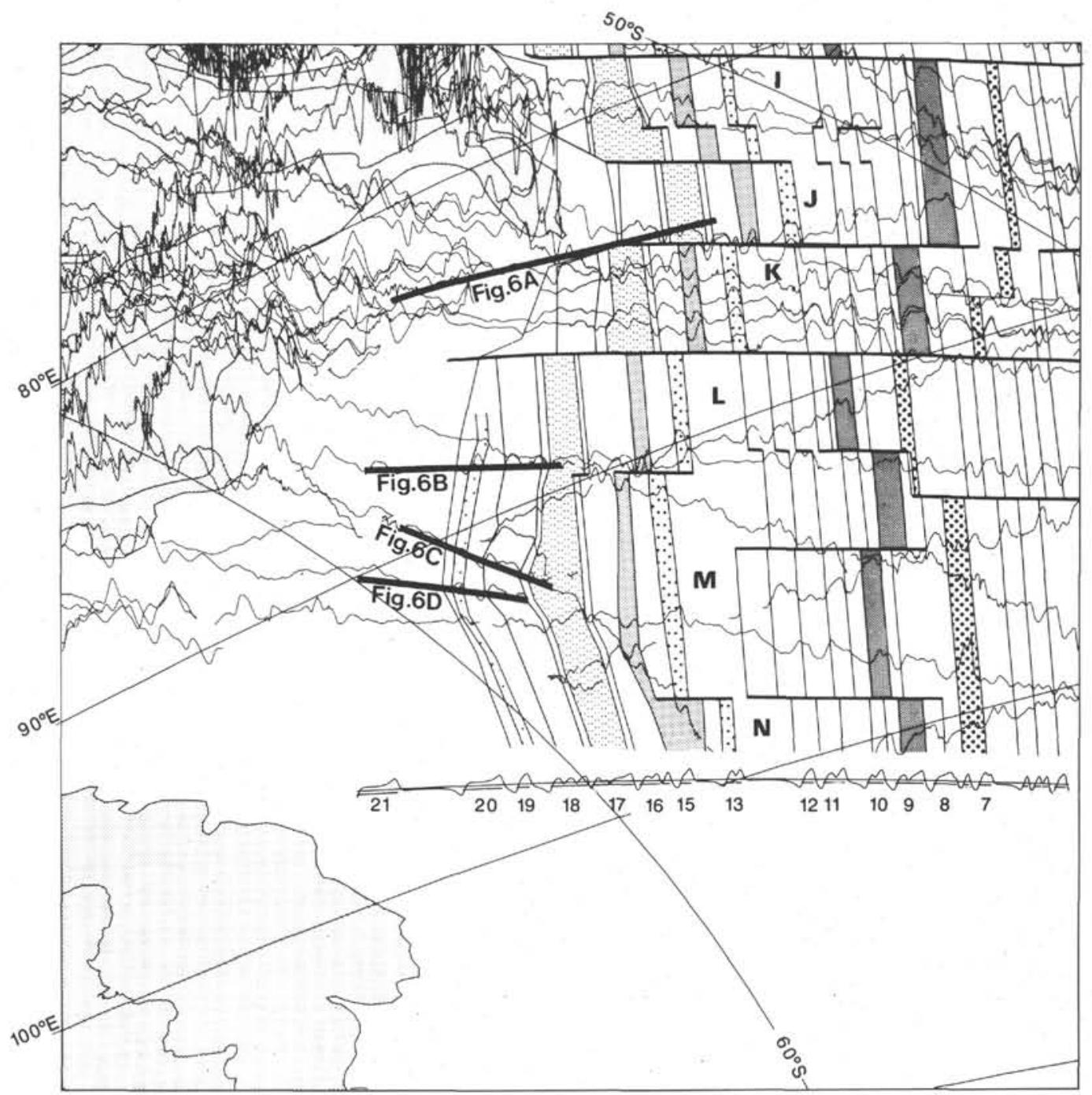

Figure 5. Magnetic anomalies and identified lineations east of the Southern Kerguelen Plateau between Anomalies 19 and 9 in Compartments I to N. A perspective projection centered on $58^{\circ} \mathrm{S}$ and $93^{\circ} \mathrm{E}$ is used with an inclination of $56^{\circ}$ and a declination of $-55^{\circ}$. The corresponding synthetic magnetic profile is shown for reference.

southern escarpment off Broken Ridge (Markl, 1974), whereas a sedimentary accumulation prevails at the foot of the northeastern escarpment of the Northern Kerguelen Plateau (Houtz et al., 1977).

Numerous profiles cross the boundary between the Northern Kerguelen Plateau and the Australian-Antarctic Basin (Fig. 8). Many of them include single or multichannel seismic data. The complete sequence of Magnetic Anomalies 18-13 was easily identified, and the fracture zone locations were well constrained. The mean half-spreading rate is $28.1 \mathrm{~km} / \mathrm{m} . \mathrm{y}$. and the mean spreading direction is $\mathrm{N} 40^{\circ}$. In this area, Southeast Indian Ridge segmentation has not been substantially modified since $42 \mathrm{Ma}$, except in Compartment $\mathrm{G}$ where a ridge jump toward the southwest occurred at $37 \mathrm{Ma}$. No magnetic anomalies older than Anomaly 18 were observed at the foot of the plateau.

South of Broken Ridge, only five magnetic profiles allow anomaly identifications (Fig. 9). Magnetic lineations were constructed from these identifications and from the conjugate lineations located near the Northern Kerguelen Plateau. The mean half-spreading rate is $27.7 \mathrm{~km} / \mathrm{m}$.y. and the mean direction is $\mathrm{N} 115^{\circ}$.

The precise boundary between the Northern Kerguelen Plateau and the crust created at the Southeast Indian Ridge was more difficult to locate than for the Labuan Basin (Fig. 9). The distance between the flank of the Northern Kerguelen Plateau and the oldest identified magnetic anomaly (Anomaly $18 \mathrm{o}$ ) ranges from 5 (to the northwest) to $80 \mathrm{~km}$ (to the southeast). In Compartments $\mathrm{G}$ and $\mathrm{H}$, this distance is about $5 \mathrm{~km}$; the boundary, therefore, was located at the foot of the plateau flank. In Compartments I and J, the distance reaches 80 and $69 \mathrm{~km}$, respectively. Along these zones, the basement observed on the seismic sections is complex. However, at the foot of the plateau and similar to the Labuan Basin, tiltedblock morphology was observed, and the boundary between the Northern Kerguelen Plateau and the Southeast Indian Ridge was located about $50 \mathrm{~km}$ from the plateau flank. Thus, the $50-\mathrm{km}$-wide zone of tilted blocks appears to be a downfaulted part of the Kerguelen Plateau basement. The age of the boundary, deduced by extrapolation of the spreading rate 
A
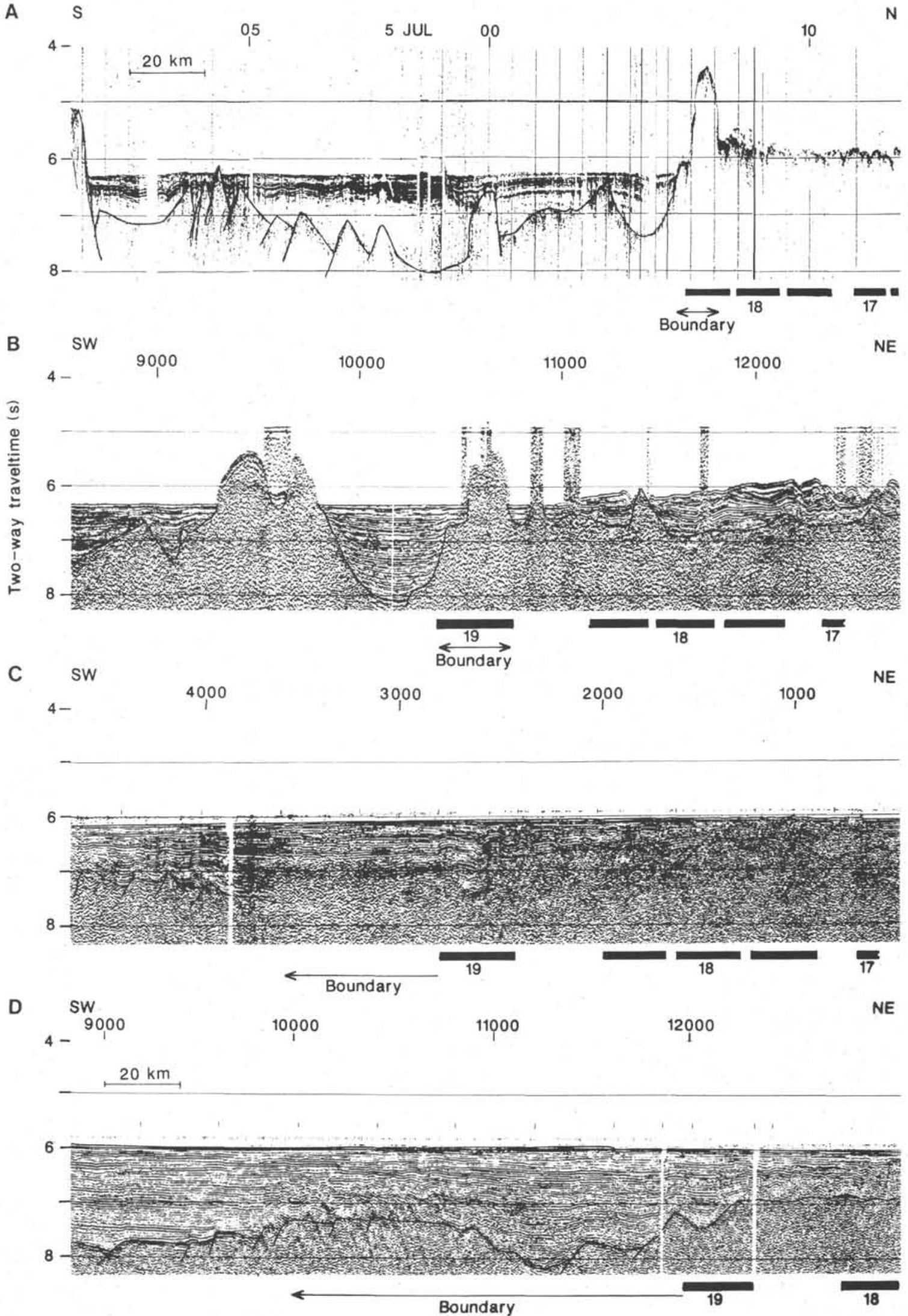

Figure 6. Seismic profiles across the boundary between the Labuan Basin and the Southeast Indian Ridge. Normal polarity periods are shown by heavy lines below each seismic profile. A. Eltanin 54-02. B. Rig Seismic 02-33. C. Marion Dufresne 47-10. D. Marion Dufresne 47-08. 


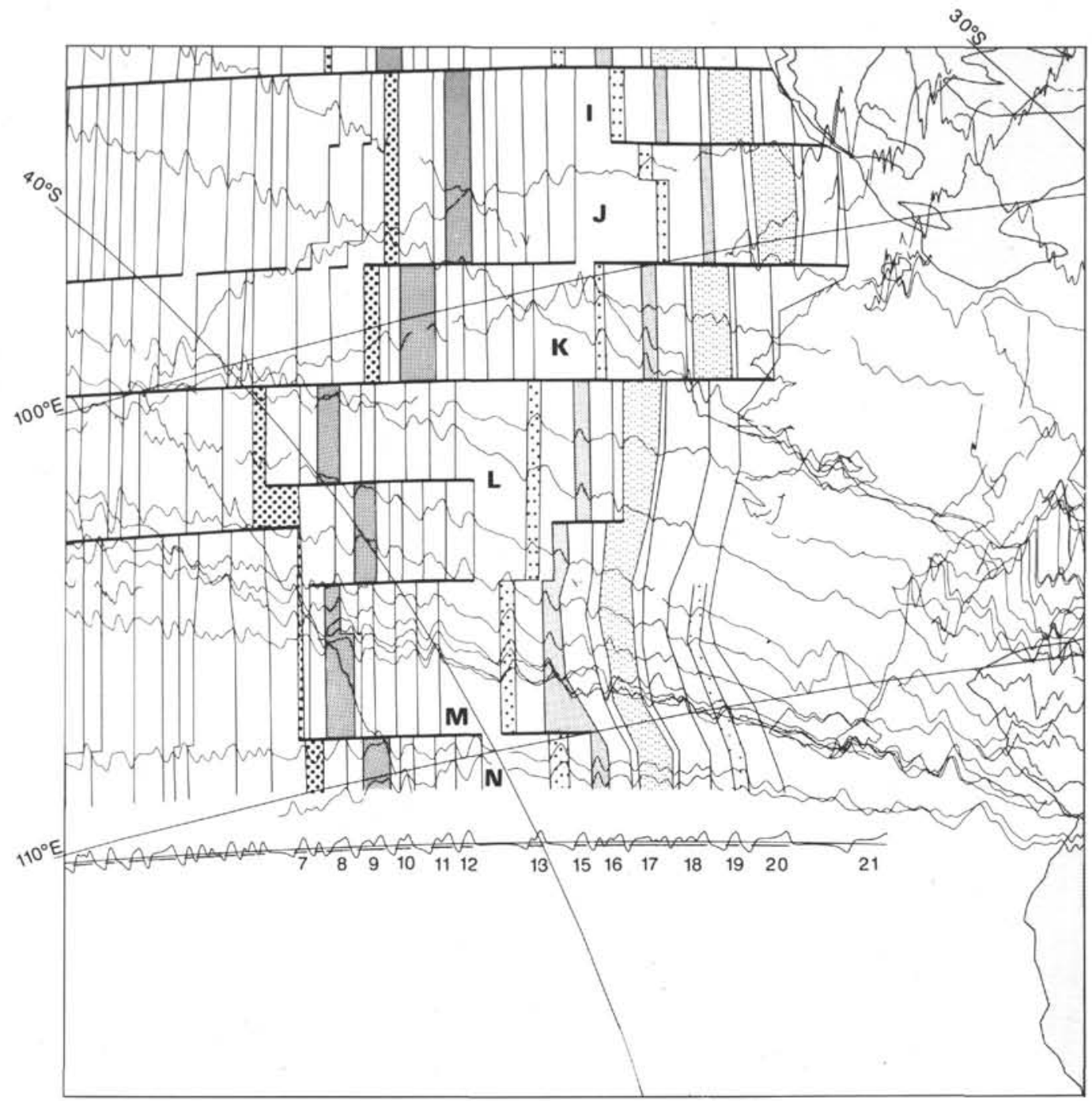

Figure 7. Magnetic anomalies and identified lineations south of the Diamantina Zone between Anomalies 19 and 9 in Compartments I to $\mathrm{N}$. A perspective projection centered on $38^{\circ} \mathrm{S}$ and $107^{\circ} \mathrm{E}$ is used with an inclination of $56^{\circ}$ and a declination of $-70^{\circ}$. The corresponding synthetic magnetic profile is shown for reference.

between Anomalies 13 and 18, averages 43.1 Ma, ranging between 42.9 and $43.8 \mathrm{Ma}$.

South of Broken Ridge, no seismic profiles have been published. We assume that the boundary between Broken Ridge and the Southeast Indian Ridge flank lies at the southern limit of the $\mathrm{Ob}$ Trench. Thus, the boundary was drawn using the bathymetric data south of Broken Ridge. The age of the boundary, deduced by extrapolation of the spreading rate between Anomalies 13 and 18, averages $43.3 \mathrm{Ma}$, ranging between 42.9 and $43.8 \mathrm{Ma}$.

\section{The Northeastern Boundary of the Northern Kerguelen Plateau North of $48^{\circ} \mathrm{S}$ and the Southern Boundary of the Ninetyeast Ridge}

The northeastern flank of the Northern Kerguelen Plateau north of $48^{\circ} \mathrm{S}$ and the southern flank of the Ninetyeast Ridge are characterized by gentle slopes with no preferential direction, as also observed on the SEASAT gravity map (Coffin et al., 1986). The northernmost part of the Kerguelen Plateau was covered by numerous bathymetric and magnetic profiles; however, no seismic profile exists in this area. The southern- most part of the Ninetyeast Ridge was poorly covered by shipboard geophysical data.

Compartment $\mathrm{F}$ is bounded by large offset fracture zones (Fig. 8). The oldest clearly observed magnetic anomaly is Anomaly 9 ( $28 \mathrm{Ma})$. Anomalies older than Anomaly 9 could be identified, but a high-frequency component in the magnetic signal progressively appears on the plateau toward Kerguelen Island. Goslin (1981) tried to remove this high-frequency component using an upward continuation filter (the magnetic anomaly profiles were computed for an altitude of $1.85 \mathrm{~km}$ ), and tentatively identified Anomaly 13; he also suggested the presence of Anomalies 15 and 16. In a similar way, Royer and Sandwell (1989) assumed that Anomaly 13 exists in this compartment.

Anomalies 13-18 were clearly identified in Compartments C, D, and E located north of Compartment F. They were also identified in Compartment G. It would be surprising if Compartment $\mathrm{F}$ were to be significantly younger than the two adjacent compartments. Several authors (Schlich, 1975, 1982; Houtz et al., 1977; Goslin, 1981; Mutter and Cande, 1983; Royer and Sandwell, 1989) have proposed that this part of the 


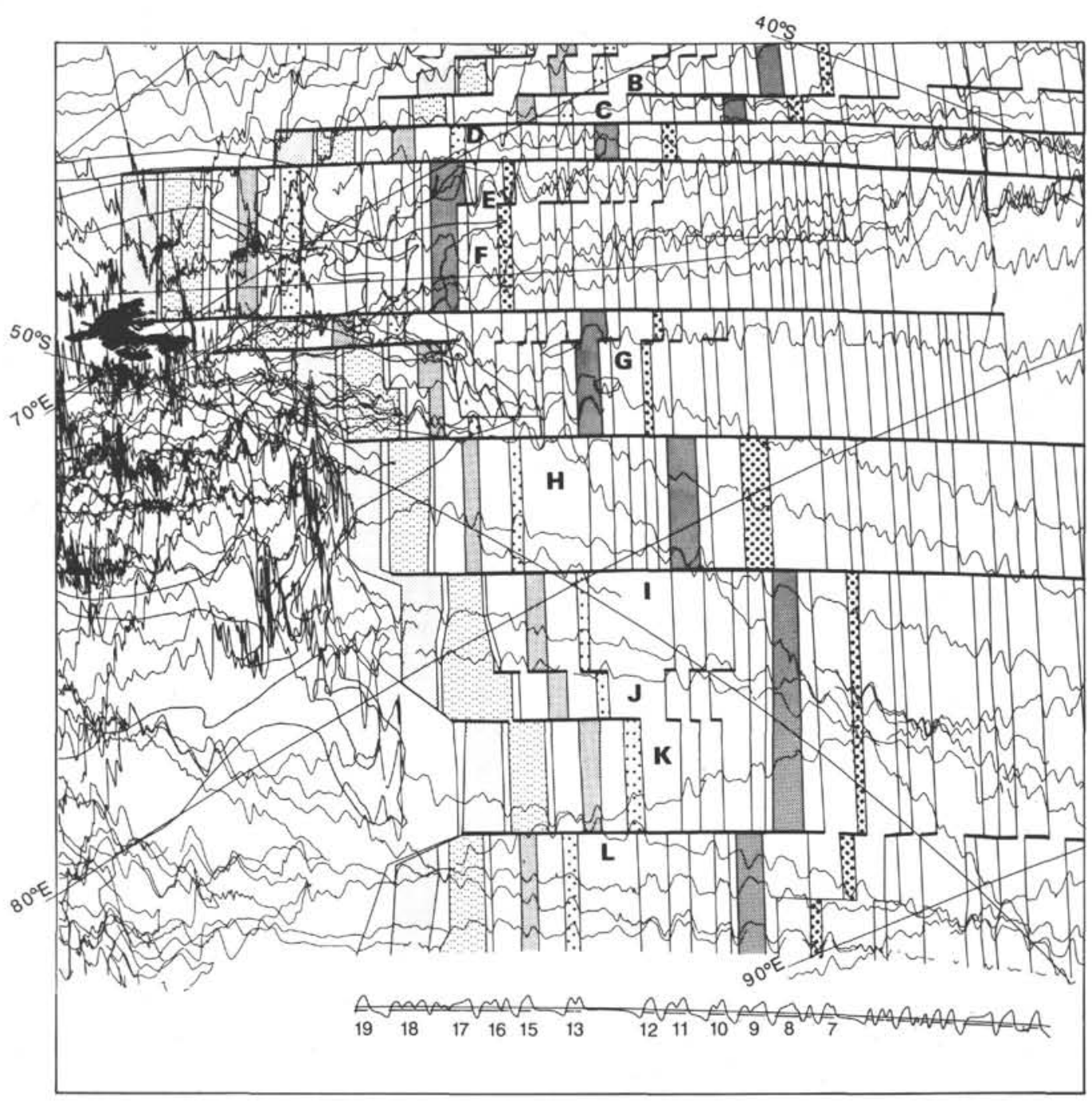

Figure 8. Magnetic anomalies and identified lineations east of the Northern Kerguelen Plateau between Anomalies 18 and 9 in Compartments B to L. A perspective projection centered on $50^{\circ} \mathrm{S}$ and $80^{\circ} \mathrm{E}$ is used with an inclination of $56^{\circ}$ and a declination of $-47^{\circ}$. The corresponding synthetic magnetic profile is shown for reference.

Kerguelen Plateau is younger and covers oceanic crust created at the Southeast Indian Ridge axis. This hypothesis is supported by the following facts: (1) only one compartment lacks clearly identified Anomalies $18-13$; (2) the Northern Kerguelen Plateau slope is very smooth with no preferential direction; (3) magnetic anomalies are progressively hidden by a high frequency signal; (4) no unique signature was observed on the SEASAT data (Coffin et al., 1986) in contrast to the other edges of the Kerguelen Plateau. Therefore, we have drawn magnetic lineations in Compartment F for Anomalies 13-18 using the same spreading rate and direction as in the two adjacent compartments. It is interesting to note that Kerguelen Island is located at the intersection of Anomaly 18 with a large dextral fracture zone. Several bathymetric highs, which could be volcanic constructions similar to Kerguelen Island, also exist at the end of the other presumed fracture zones (Fig. 8). Geological studies of Kerguelen Island show that the volcanic activity has occurred from 39 Ma until now (Giret, 1983). We propose that part of the Northern Kerguelen Plateau was formed after Anomaly 18 by excess volcanism; the lava flows covered a part of the newly created oceanic crust in Compartment F. The boundary between the "old" Northern Kerguelen Plateau and the oceanic crust at the Southeast Indian Ridge probably lies at Anomaly 18, as observed for the adjacent compartments.

South of the Ninetyeast Ridge, no magnetic profiles were available in Compartment $\mathrm{F}$ for anomalies older than Anomaly 7 (Fig. 9). Thus, it is not possible to check our hypothesis on the age of Compartment F. Magnetic profiles in this part of the compartment must be collected because the depth of the crust in the western part of the compartment appears to be normal and a normal sequence of magnetic anomalies can be expected. If our hypothesis for the age of Compartment $\mathrm{F}$ is correct, it is interesting to note that more lava was erupted after Anomaly 18 on the Antarctic Plate than on the Australian Plate.

\section{DISCUSSION AND CONCLUSION}

Taking into account all of the available geophysical data and using an interactive graphic software, we have defined a detailed structural scheme for the Australian-Antarctic and South Australian basins between the Kerguelen Plateau and 


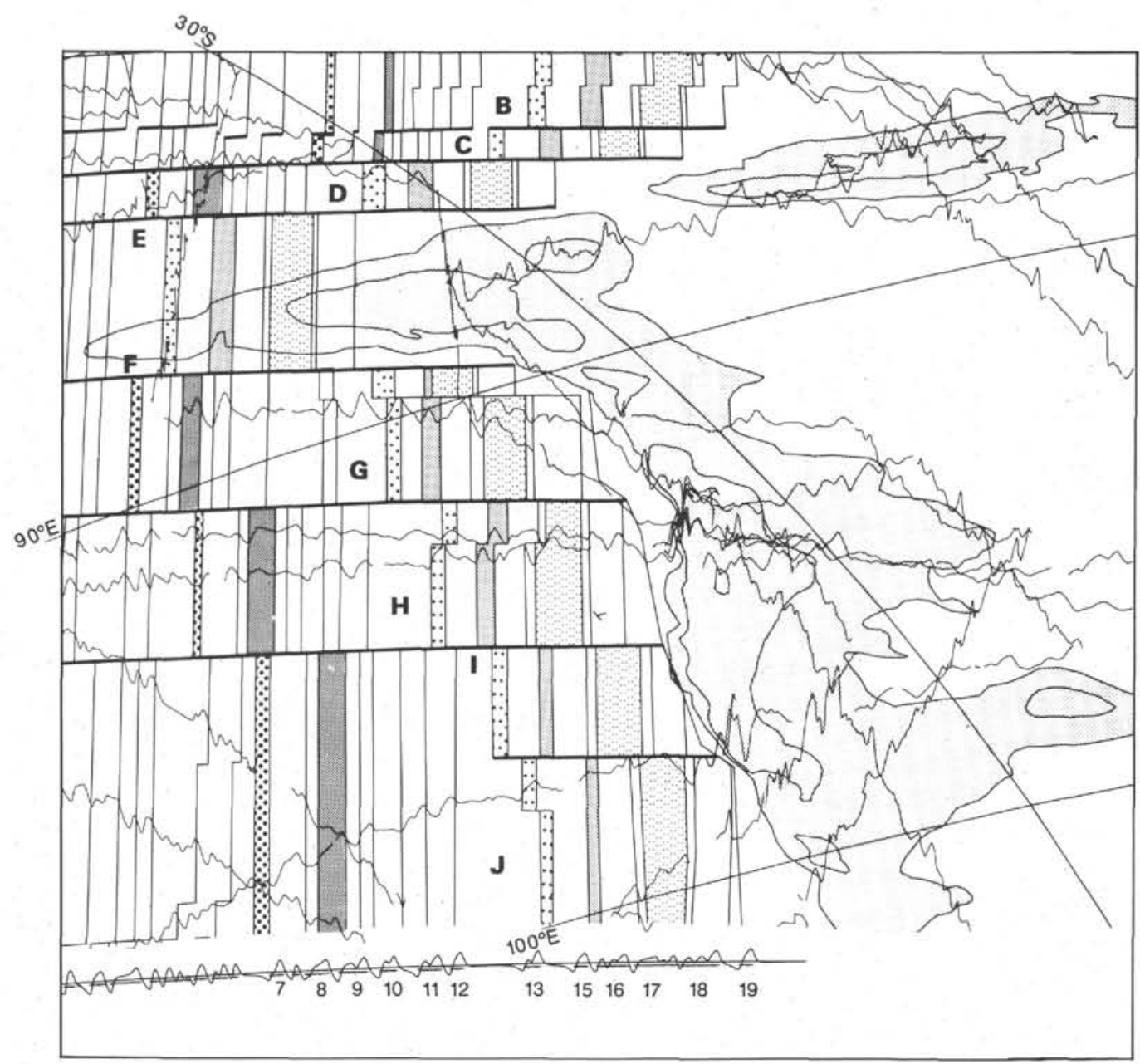

Figure 9. Magnetic anomalies and identified lineations south of Broken Ridge between Anomalies 19 and 9 in Compartments B to J. A perspective projection centered on $33^{\circ} \mathrm{S}$ and $95^{\circ} \mathrm{E}$ is used with an inclination of $56^{\circ}$ and a declination of $-63^{\circ}$. The corresponding synthetic magnetic profile is shown for reference.

Broken Ridge. In this area, data coverage is irregular; thus, the accuracy of the proposed structural scheme is variable. In particular, profiles south of Broken Ridge are very sparse, and the tectonic scheme has been derived from the conjugate area. However, the regular coverage of SEASAT data helps to constrain the fracture zone location. About 4,600 magnetic picks have been identified and 53 isochrons have been drawn.

The four JOIDES Resolution transit lines between Australia and the Kerguelen Plateau in Compartment $\mathrm{L}$ provide important information for the detailed study of the seafloor spreading pattern in this compartment. Several changes of spreading rate were observed, and rates generally increased from Anomaly 5 to 1 . Superimposed on this general trend are two important changes: one at Anomaly 4-3A, and another at the Jaramillo Event; these are related to changes in spreading direction. Similar changes of seafloor spreading were also observed between Australia and Antarctica (Vogt et al., 1983). Generally, the Australian-Antarctic and South Australian basins display a regular tectonic fabric without major changes in spreading rate or direction. Most of the main transform faults existed since the separation of the Kerguelen Plateau and Broken Ridge.

The boundaries between the Northern Kerguelen Plateau south of $48^{\circ} \mathrm{S}$, Labuan Basin, Broken Ridge, and Diamantina
Zone on the one hand, and the Australian-Antarctic and South Australian Basin on the other, were clearly identified and are $<90 \mathrm{~km}$ wide. Northeastward from the Kerguelen Plateau and southward from Broken Ridge, the boundaries were located at the foot of the plateau flanks; their ages lie between 43.8 and 42.9 Ma. No significant age variation was observed along the boundary in this area. Northeastward from the Labuan Basin and southward from the Diamantina Zone, the boundary does not correspond to any bathymetric feature, but it was clearly recognized on the magnetic and seismic profiles. In this area, the boundary is older and varies in age from 46.0 to $43.0 \mathrm{Ma}$ from east to west; the breakup propagated westward at a velocity of about $300 \mathrm{~km} / \mathrm{m}$.y. in this area.

The boundary between the Northern Kerguelen Plateau north of $48^{\circ} \mathrm{S}$ and the southern end of the Ninetyeast Ridge on the one hand, and the Australian-Antarctic Basin on the other, is covered by post-breakup lava flows. In these two areas, the magnetic lineations and the boundary were extrapolated from data located in adjacent compartments. It is interesting to note that Kerguelen Island is located at the intersection of this boundary with a large fracture zone (100-km dextral offset).

From 46.0 to $43.0 \mathrm{Ma}$, the breakup between the Kerguelen Plateau-Labuan Basin and the Broken Ridge-Diamantina Zone propagated from east to west. The breakup between 
Australia and Antarctica occurred at $96 \mathrm{Ma}$, and the two plates moved about $500 \mathrm{~km}$ between $96 \mathrm{Ma}$ and Anomaly 19 (44 Ma) (Powell et al., 1988; Royer and Sandwell, 1989). Therefore, deformation took place during this time span on the Kerguelen Plateau-Labuan Basin and the Broken RidgeDiamantina Zone. Two extensional tectonic phases have been recognized on the Kerguelen Plateau and in the Labuan Basin (Rotstein et al., 1991; Fritsch et al., this volume; Munschy et al., this volume) at 88-87 and 69-66 Ma; extension was also observed in the Diamantina Zone. There is not enough seismic data, however, to compute the amount of horizontal stretching. Thus, the deformation produced by the drift between Australia and Antarctica from 96 to 44 Ma could be explained by stretching of the Kerguelen Plateau-Labuan Basin and the Broken Ridge-Diamantina Zone; however, strike-slip motion between the western Diamantina Zone and Australia and/or between the Kerguelen Plateau and Antarctica cannot be definitively excluded.

The development of rifting between the Kerguelen Plateau-Labuan Basin and the Broken Ridge-Diamantina Zone, and the evolution of the Southeast Indian Ridge can be summarized as follows:

1. From 96 to $46 \mathrm{Ma}$, slow spreading occurred between Antarctica and Australia; the Kerguelen Plateau, Labuan Basin, and Diamantina Zone stretched at 88-87 and 69-66 Ma.

2. From 46 to $43 \mathrm{Ma}$, the breakup between the Southern Kerguelen Plateau and the Diamantina Zone propagated westward at a velocity of about $300 \mathrm{~km} / \mathrm{m}$.y. Breakup between the Northern Kerguelen Plateau and Broken Ridge occurred between 43.8 and $42.9 \mathrm{Ma}$.

3. After $43 \mathrm{Ma}$, volcanic activity developed on the Northern Kerguelen Plateau and at the southern end of the Ninetyeast Ridge. Lava flows obscured the boundaries of the Northern Kerguelen Plateau north of $48^{\circ} \mathrm{S}$ and the Ninetyeast Ridge south of $32^{\circ} \mathrm{S}$, covering part of the newly created oceanic crust. Since $43 \mathrm{Ma}$, the Southeast Indian Ridge has displayed a typical intermediate spreading rate $(25-45 \mathrm{~km} / \mathrm{m} . \mathrm{y}$.).

\section{ACKNOWLEDGMENTS}

M. Munschy, R. Schlich, and M. F. Coffin thank the Ocean Drilling Program for inviting them to participate on Leg 120 aboard the JOIDES Resolution. The authors thank E. Barbu, J. Peirce, J. Y. Royer, and J. Weissel for critical reviews and comments on the original version of the manuscript. We also thank Monique Blanck for drafting the figures. We are grateful to Territoire des Terres Australes et Antarctiques Françaises for their support on board Marion Dufresne. This work was supported by Centre National de la Recherche Scientifique (ODP-France).

\section{REFERENCES}

Berggren, W. A., Kent, D. V., Flynn, J. J., and Van Couvering, J. A., 1985. Cenozoic geochronology. Geol. Soc. Am. Bull., 96:1407-1418.

Cande, S. C., and Mutter, J. C., 1982. A revised identification of the oldest sea-floor spreading anomalies between Australia and Antarctica. Earth Planet. Sci. Lett., 58:151-160.

Coffin, M. F., Davies, H. L., and Haxby, W. F., 1986. Structure of the Kerguelen Plateau province from SEASAT altimetry and seismic reflection data. Nature, 324:134-136.

Fröhlich, F., Caulet, J. P., Clément, P., Fellah, N., Giannesini, J. P., Wicquart, E., Avérous, P., Blanc, G., Giannoni, A., Martin, L., Phillipot, F., and Prost, S., 1983. Mise en évidence d'une série sédimentaire pélagique du Paléogène et du Cráetacé Supérieur sur le plateau de Kerguelen: résultats préliminaires de la campagne océanographique MD35 D.R.A.K.A.R. (mars 1983) du N.O. Marion Dufresne. C. R. Acad. Sci. Ser. 2, 297:153-156.
Giret, A., 1983. Le plutonisme océanique intraplaque. Exemple de l'archipel des Kerguelen. Territoire des Terres Australes et Antarctiques Françaises [Ph.D. thesis]. Univ. P. et M. Curie, Paris.

Goslin, J., 1981. Etude géophysique des reliefs asismiques de l'océan Indien occidental et austral [Ph.D. thesis]. Univ. Louis Pasteur, Strasbourg, France.

Hayes, D. E., and Conolly, J. R., 1972. Morphology of the Southeast Indian Ocean. In Hayes, D. E. (Ed.), Antarctic Oceanology (Vol. 2): Am. Geophys. Union, Antarct. Res. Ser., 19:125-145.

Heezen, B. C., and Tharp, M., 1965. Physiography of the Indian Ocean. Philos. Trans. R. Soc. London, A259:137-149.

Houtz, R. E., Hayes, D. E., and Markl, R. G., 1977. Kerguelen Plateau bathymetry, sediment distribution and crustal structure. Mar. Geol., 25:95-130.

Houtz, R. E., and Markl, R. G., 1972. Seismic profilers data between Antarctica and Australia. In Hayes, D. E. (Ed.), Antarctic Oceanology (Vol. 2): Am. Geophys. Union, Antarct. Res. Ser, 19:147164.

Le Pichon, X., and Heirtzler, J. R., 1968. Magnetic anomalies in the Indian Ocean and sea-floor spreading. J. Geophys. Res., 73:21012117.

Li, Z. G., 1988. Structure, origine et évolution du plateau de Kerguelen [Thèse de Doctorat]. Univ. Louis Pasteur, Strasbourg, France.

Luyendyk, B. P., and Rennick, W., 1977. Tectonic history of aseismic ridges in the eastern Indian Ocean. Geol. Soc. Am. Bull., 88:13471356.

Macdonald, K. C., 1982. Mid-ocean ridges: fine scale tectonic, volcanic and hydrothermal processes within the plate boundary zone. Annu. Rev. Earth. Planet. Sci., 10:155-190.

Mammerickx, J., and Sandwell, D., 1986. Rifting of old oceanic lithosphere. J. Geophys. Res., 91:1975-1988.

Markl, R. D., 1974. USNS Eltanin Cruise 54 to Kerguelen Plateau and Southeast Indian Ridge. Antarctic J., 8:6-8.

1978. Basement morphology and rift geometry near the former junction of India, Australia, and Antarctica. Earth Planet. Sci. Lett., 39:211-225.

McKenzie, D. P., and Sclater, J. G., 1971. The evolution of the Indian Ocean since the Late Cretaceous. Geophys. J. R. Astron. Soc., 25:437-528.

Morgan, W. J., 1978. Rodrigues, Darwin, Amsterdam-a second type of hotspot island. J. Geophys. Res., 83:5355-5360.

Munschy, M., and Schlich, R., 1987. Structure and evolution of the Kerguelen-Heard Plateau (Indian Ocean) deduced from seismic stratigraphy studies. Mar. Geol., 76:131-152.

Mutter, J. C., and Cande, S. C., 1983. The early opening between Broken Ridge and Kerguelen Plateau. Earth Planet. Sci. Lett., 65:369-376.

Mutter, J. C., Hegarty, K. A., Cande, S. C., and Weissel, J. K., 1985. Breakup between Australia and Antarctica: a brief review in the light of new data. Tectonophysics, 114:255-279.

Norton, I. O., and Molnar, P., 1977. Implications of a revised fit between Australia and Antarctica for the evolution of the eastern Indian Ocean. Nature, 267:338-339.

Norton, I. O., and Sclater, J. G., 1979. A model for the evolution of the Indian Ocean and the breakup of Gondwanaland. J. Geophys. Res., 84:6803-6830.

Peirce, J., Weissel, J., et al., 1989. Proc. ODP, Init. Repts., 121:College Station, TX (Ocean Drilling Program).

, in press. Proc. ODP, Sci. Results, 121: College Station, TX (Ocean Drilling Program).

Powell, C. M., Roots, S. R., and Veevers, J. J., 1988. Pre-breakup continental extension in East Gondwanaland and the early opening of the Eastern Indian Ocean. Tectonophysics, 155:261-283.

Ramsay, D. C., Colwell, J. B., Coffin, M. F., Davies, H. L., Hill, P. J., Pigram, C. J., and Stagg, H.M.J., 1986. New findings from the Kerguelen Plateau. Geology, 14:589-593.

Rotstein, Y., Munschy, M., Schlich, R., and Hill, P. J., 1991. Structure and early history of the Labuan Basin, southern Indian Ocean. J. Geophys. Res., 96:3887-3904.

Royer, J. Y., 1985. Evolution cinématique détaillée de la dorsale est-indienne entre le point triple de Rodriguez et les îles Saint-Paul et Amsterdam. [Ph.D. thesis]. Univ. Louis Pasteur, Strasbourg, France. 
Royer, J. Y., and Sandwell, D. T., 1989. Evolution of the eastern Indian Ocean since the Late Cretaceous: constraints from Geosat altimetry. J. Geophys. Res., 94:13755-13782.

Royer, J. Y., and Schlich, R., 1988. Southeast Indian Ridge between the Rodriguez Triple Junction and the Amsterdam and Saint Paul islands: detailed kinematics for the past 20 m.y. J. Geophys. Res., 93:13524-13550.

Schlich, R., 1975. Structure et âge de l'océan Indien occidental. Mem. Hors-Ser. Soc. Geol. Fr., 6:1-103.

1982. The Indian Ocean: aseismic ridges, spreading centers, and oceanic basins. In Nairn, A.E.M., and Stehli, F. G. (Eds.), The Ocean Basins and Margins (Vol. 6): New York (Plenum), 51-147.

Schlich, R., and Patriat, P., 1967. Profils magnétiques sur la dorsale médio-océanique "Indo-Pacifique." Ann. Geophys., 23:629-633.

1971. Anomalies magnétiques de la branche Est de la dorsale médio-indienne entre les îles Amsterdam et Kerguelen. $C$. R. Acad. Sci. Ser. 2, 272:700-703.

Schlich, R., Wise, S. W., Jr., et al., 1989. Proc. ODP, Init. Repts., 120: College Station, TX (Ocean Drilling Program).

Talwani, M., Mutter, J. C., Houtz, R. E., and König, M., 1978. The crustal structure and evolution of the area underlying the magnetic quiet zone on the margin south of Australia. AAPG Mem., 29:151-175.

Vogt, P. R., Cherkis, N. Z., Feden, R. H., Kovacs, L. C., Fleming, H. S., Morgan, G. A., Hill, P. J., Whitworth, R., and Tilbury, L. A., 1983. Project Investigator 1: Australian Antarctic Discordance aeromagnetic investigations. Bur. Mineral Res. Aust.

Weissel, J. K., and Hayes, D. E., 1972. Magnetic anomalies in the southeast Indian Ocean. In Hayes, D. E. (Ed.), Antarctic Oceanology (Vol. 2): Am. Geophys. Union Antarct. Res. Ser., 19:165196.

Wicquart, E., 1983. Modèle lithostratigraphique du plateau de Kerguelen-Heard, océan Indien [Thèse de troisième cycle]. Univ. Pierre et Marie Curie, Paris, France.

Wicquart, E., and Fröhlich, F., 1986. La sédimentation sur le plateau de Kerguelen-Heard: relations avec l'évolution de l'océan Indien au Cenozoique. Bull. Soc. Geol. Fr., 8:569-574.

Date of initial receipt: 17 October 1990

Date of acceptance: 26 February 1991

Ms 120B-123 